DANDELION

postgraduate arts journal \& research network

VOLUME 7 NUMBER I SUMMER 2016
Martina Massarente is a PhD student in the Digital Humanities, Art, and Multimedia Technology department at the University of Genoa. Her thesis, 'Photography as a Tool for History of Art: From the Early Study Methods to New Technologies', investigates the role of photography in the teaching and pedagogy of Art History. An integral part of her dissertation focuses on the foundation, management, archiving, and digitalisation of glass slides belonging to the first professor of the History of Art at the University of Genoa, Giusta Nicco Fasola. Martina also works as a freelance curator.

martina.massarente@edu.unige.it

Article

\title{
Decadent Nostalgia \\ Neo-Gothic Remakes and Reinterpretations in Contemporary Photography and Video Art
}

\author{
Martina Massarente
}

THIS ARTICLE WILL OFFER A SURVEY OF THE RECOVERY AND TRANSFORMATION OF NEO-GOTHIC VICTORIAN STYLE IN CONTEMPORARY ART, focussing in particular on recent developments in musical performance, videography, and photography. After an initial discussion on what is symbolically and historically at stake in the Neo-Gothic, the essay will turn towards an analysis of texts that are emblematic of this revival in the fortunes of a Neo-Gothic aesthetic. Considering the vastness of the subject and the myriad stylistic articulations that derive from the genre of 'gothic remake', the essay will restrict itself to a limited number of artists who, whilst noted in their own disciplines, lack wider recognition. Working across a range of visual mediums, these artists refer to the past and simultaneously bring an originality of their own to the material, going beyond any hackneyed revivalism.

Any history of the Gothic, especially one that tracks its spiritual and aesthetic architecture, must necessarily pass through two distinct historical movements: for the Pre-Raphaelites, the accent lay firmly on the search for a lifestyle that was both spiritually pure and connected to artisanal forms of labour, with an eye turned to medieval literature. The second recrudescence is more recent; born around the late Seventies and developing steadily throughout the Eighties, this evolution started in music initially, before germinating all other areas of cultural production.

Luca Beatrice addresses this subject in his essay 'Gothland: The PreRaphaelite Enigma between Music, Fashion, Cinema and Art', which, written 
to mark the opening of the 'Pre-Raphaelites' exhibition in Turin (Palazzo Chiablese, April $18^{\text {th }}$-July $\left.13^{\text {th }}, 2014\right)$, proposes an inquiry into the ongoing influence the movement has on contemporary culture, habits and society. Beatrice detects in the Pre-Raphaelites, artistic trends that have, in the contemporary age, coalesced to give birth to 'New Gothic', 'a style that has contaminated art as well as music, cinema and fashion'. ${ }^{1}$ Further still, Beatrice identifies the Pre-Raphaelites as 'involuntary precursors of the postmodern': 'taking a dark, unexplored period in the history of art such as the Gothic, bringing to light something from very far away, and above all playing in a sort of suspended time'. ${ }^{2}$ Such themes remain important stimulants for artistic practice today.

Following a brief overview of the neo-gothic, section two will concentrate on the cult performer Sopor Aeternus and The Ensemble of Shadows, an artist whose work has yet to receive the scholarly attention it warrants. Sopor Aeternus best exemplifies the eclectic recovery of a lifestyle that is close to the first iteration of the gothic headed by the Pre-Raphaelite Brotherhood, and to a personal, physical, and performative evolution, not just of the Victorian style, but also of some expressive components that come from symbolism, art nouveau and art deco funerary sculptures. Moving outwards from the music, which combines a range of funeral sounds, Sopor Aeternus recreates a corporeality that is presented to the public through a collection of symbols and icons that belong to a medieval, gothic, and Victorian past. Section three will consider the American 'freak folk' duo CocoRosie, using the music video for their song 'Gallows' as the privileged object of study. Assembled out of Gothic and Victorian imagery, 'Gallows' maps the contours of the neo-gothic remake in the contemporary period. The musical genres and the visual contexts in which these artists move are subject to a continuous historical blending: they are innervated by cultures born of a movement that has drawn its lifeblood from the Victorian age and the Pre-Raphaelite Brotherhood. The final section will, in turn, examine the re-appropriation of the neo-gothic in photography, analysing artists who have drawn on Pre-Raphaelite painting and a lust for ruins. The central reference point of this concluding section will be John Everett Millais's Ophelia and the influence this painting has exerted over the contemporary tableaux vivants image. Under consideration here will be the work of Silvia Camporesi, Tom Hunter, Gregory Crewdson and Brooke Shaden; photographers who have all responded, if in different and at times antagonistic ways, to Millais seminal painting.

As Italian professor of philosophy Oscar Meo states, 'style is the way in which man inhabits the world', 'a drawing out of meanings'. ${ }^{3}$ More precisely, 'having a personal style' and 'belonging to a particular style' are two concepts that make it possible to understand the contemporary remake culture, meaning that the recovery of a style from the past, displaced from its historical context, is reintegrated into a different period, and made one's own. ${ }^{4}$ The fact of belonging to a style 'refers to a behaviour [...] a way of being or of acting in certain life circumstances within the context of the social, cultural sphere', whilst 'having style' means 'belonging to a certain standard, following a general model encoded within a certain socio-cultural tradition.. ${ }^{5}$ Such definitions prove helpful when approaching the Neo-Gothic; a style that has evolved out of a range of subcultures and aesthetic trends that maintain a certain affinity to a way or quality of life that is connected to Gothic culture. It goes without saying 
that within the popular imagination, the gothic has greatest visibility in youth culture, with fashion serving as a particularly stark example of identities that have created an alternative lifestyle to the one prescribed by mainstream society. Annual music festivals attract tens of thousands of attendees: the most famous of which is Wave-Gotik-Treffen, a celebration 'held in Leipzig over the Pentecost weekend'. ${ }^{6}$ More recently, a Steampunk convention, organised in Genoa under the name Steampunk Invasion, in collaboration with Steampunk Italia, represents both the further evolution in the Neo-Gothic and its growing popularity. ${ }^{7}$

As highlighted above, the Neo-Gothic had a particular stylistic vibrancy and resonance in the 1980s, a period in which it expanded from its historic birthplace in England to encompass the whole world. Today, nostalgia for NeoGothic aesthetics, in particular the recovery of styles and habits from the Victorian era, constitute an important field for investigation, characterised by the presence of theories and attitudes that define Neo-Gothic peculiarities, transforming them into distinctive voices for the contemporary era. The NeoGothic, first identified with Romanticism before being subject to modification by Symbolism and Decadentism, is now associated with a plethora of subcultures whose borders are not only porous but are thoroughly indefinable. ${ }^{8}$ If the 'antiquity' of modern Neo-Gothic is Pre-Raphaelite culture, then it may possible to suggest that 'the key to its longevity is in having evolved into a wide diversification, while maintaining common roots that are connected to a precise aesthetic, to Gothic literature, horror cinema and, in come case, fetish sexuality'.

Contemporary invocations of a Neo-Gothic sensibility can be seen in the differentiated subculture of steampunk, emo, dark romantic and Industrial goth. ${ }^{10}$ The subcultures that come from the recovery of the Neo-Gothic style are 'cultures in perpetual evolution', blending together musical, stylistic, aesthetic, and intellectual currents, giving birth to a wide range of filiations and new sub genres that, often, do not allow an adequate or precise definition. These facets are most noticeable in music; emerging out of punk, goth-rock unleashed a host of diffuse creative spirits such as darkwave, deathrock, ethereal and industrialeach with their own further subcategories, Victorian Industrial to name only one- now considered as the new 'punks' of the contemporary era. ${ }^{11}$ According to Giovanni Di Iacovo, there are four macrocategories inside which other sub genres are defined: Industrial/experimental; electro-industrial; industrial rock; post-industrial. ${ }^{12}$ Although music was the primary trigger for some broadly defined development of Goth as a subculture in Europe and, later on in America, interest spread contagiously inside the fields of costume and performing arts. What ties the impulse to reference Victorian culture and the drive to rearticulate and make newly 'liveable' a certain gothic style, is, first of all, a shared interest in tropes from romantic literature: obsession with the paranormal; with ghost and ghoul tales; the sublime; unhappy love; and with horror at death. Indeed, the cultural roots of the Gothic can be glimpsed in 18th century British culture, in particular, Horace Walpole's The Castle of Otranto (1764), a novel widely considered as inaugurating the genre of gothic literary fiction. To be sure, there are other classic texts that have stimulated interest in the themes of death, mystery, and darkness; among those would rank Frankenstein by Mary Shelley, Dracula by Bram Stoker, The Monk by Matthew Lewis. In its American articulation it is impossible to talk about the gothic without acknowledging Edgar Allan Poe's obscure romanticism, a critical creative source for Sopor Aeternus. ${ }^{13}$

The recovery of these topics in the contemporary tends towards 
pastiche, with details, images, and concerns extracted from different eras finding themselves juxtaposed beside one another. The eighteenth century thus brushes up against the Victorian which is itself transplanted into late twentieth century iconography. This type of collaging is witnessed in the 'renaissance' of ruins, in the taste for cemeterial garden furnishing, for automaton and clockworks. $^{14}$

\section{II}

What role does the recovery of these styles play in today's artistic culture? Music and visual art were the first to fully take in the lessons of the past and to propose new models for performance and aesthetic practice. Indeed, it is in the areas of video art and contemporary photography in particular, that these advances in style and cultural evolution are most reminiscent of older debates around simulacrum and the remake. And it is this attention to questions of authenticity and originality that inform Horst Bredekamp's observations regarding the schematic and substitutive image-act, and Giuliana Bruno's considerations regarding the new geography of the contemporary body. Bredekamp and Bruno are helpful here, because they offer theoretical definitions that open up aspects of the contemporary that would otherwise be obscure. Giuliana Bruno's Atlas of Emotion: Journeys in Art, Architecture, and Film makes it possible to understand how the body can be represented and carried through film, while Horst Bredekamp, in his Theory of the Image Act, analyses the way spectators instil vitality into pictures, photographs, sculptures and paintings that, though they do not have a life of their own, can give way to a power of attraction/repulsion in the viewer that develops a presence that carries them away from their inanimate nature. ${ }^{15}$ The body becomes the main vehicle for the new performativity that developed throughout the Eighties and Nineties, a corporeality that blends with the use of photography and videos in transmitting its messages. Francesca Alfano Miglietti usefully defines such an action as 'a performative act that happens in real time, to which the audience cannot abide, in which the audience is forced to feel embarrassment, surprise, disgust, excitement. The body becomes absolute language, the medium through which the artist transforms herself, transforms her image and her identity'. ${ }^{16}$

These principles of performativity, gesture, action and reaction are the basis on which the essay intends to treat the combination of Gothic-Victorian recovery in the work of Sopor Aeternus. Formed in 1989 in Germany, Sopor Aeternus and The Ensemble of Shadows is a musical project lead by AnnaVarney Cantodea-who is considered one of the foremost dark performers in Europe today. ${ }^{17}$ Their artistic and visual work is structured according to forms of expression that then merge into a single multidisciplinary performance that combines music, poetry, and visual appearance. Recovery of the Gothic is achieved, on the one hand, through a collage of classical, electronic, baroque, and medieval sounds which are assembled into a fractured totality. On the other, the artist is surrounded by mystery, refusing to appear in public and thus confronting the audience with a performance in which the artist's image is entirely trusted to photography and video, recuperating the Gothic through the aesthetic.

If style, as Meo suggests, is a way of being in the world and interacting with it, Sopor Aeternus perfectly embodies this statement: its way of appearing in public represents what the artist feels, a personal, intimate universe. The artist appears with a diaphanous corporality, an ambiguous sexuality, dressed in black with corsets, laces and veils that are typical of the Victorian era, traceable 
to the dimension of mourning, of death and ghostly presence. This stylistic fact finds its origins in the diffusion of a particular habit that arose during Queen Victoria's reign when she was 'widowed after Prince Albert's death in 1861 [...] By dint of wearing black clothing she turns it into a habit that is still present to our day'. ${ }^{18}$ The images in which Sopor Aeternus is portrayed remind us of panoplies of contemporary vanity with roses, flowers, pearl necklaces, signs of transience and cemeterial symbols; however it is the artist's body that is the main vehicle of communication. The body becomes a trace, the remains of a presence whose physicality is doubtful. The strength in its expressiveness, something that recalls early silent and expressionist films, transforms the body into a ghost, an ectoplasm that tells tales of death, of nostalgia, of melancholy, all the while creating a temporal disjunction between a dimension that seems to belong to the past and a performing physicality that is resolutely contemporary.

Expressions of panic, a sense of hallucinated isolation caused by the visual splitting of the body are typical of an introverted exhibitionism that gives birth to an interior spiritual work transformed by art into an oblique voice of the contemporary. The fragmentation of the artist's body, reproduced in various poses and arranged inside a single image, reminds us of an emblematic theme of medieval iconography: the dance macabre. The body acts as death and as mortal at the same time, a metamorphosis of the body that takes place during a universal time, an unknown time, that recalls the Victorian decadent past of the 1900s and simultaneously expresses fears and paranoias that belong to our present. ${ }^{19}$ References to the dance macabre indicate the almost ironic touch with which Sopor Aeternus treats the subject of death and her relationship to it. Traditionally the dance macabre portrays an alternation between humans and skeletons, whereby the skeleton acts as the moral alter ego of the departed. Sopor Aeternus often appears in photographs that portray the artist chained to another self, captured in dancing poses and often in a semicircle, almost repurposing the iconography of the ancient dance macabre.

Splitting though, can also mean something else entirely. The double can be seen as a shadow; a shadow in flesh and bones, an interior tableau vivant where the different selves portrayed in the images and in the videos are the externalisation of the person's inner self. It is as though the camera had first of all been able to plunge into the person's mind through the shadow [...] the shadow, an external image, reveals what is taking place inside the character, what the person is', and Sopor Aeternus sings, dances, plays for itself, for its double, its triple, always itself, its interior voice reciting intimate, ominous poetry. ${ }^{20}$ This imagery made of funerary concerts, of an attraction towards the bond that ties life and death, shows the artist continuously participating in her own decadence, in her constant getting in the game in front of the camera to accept the fact that life has no metaphysical meaning and, for this reason, to face death ironically. And whilst reflections on mortality have never not haunted mankind, different historical periods give them distinct forms of expression; for an artist like Sopor Aeternus intellectual continuity is first with Romanticism and the Pre-Raphaelites, with spiritual purity, a sense of horror at the sublimity of nature and its destructive hold over man; and second with the rebellion against traditional society by modern generations.

Literature, in the form of horror and the uncanny, further furnishes Sopor Aeternus with an intellectual connection to the gothic tradition. Unsurprisingly, Edgar Allan Poe's work, particularly 'The Fall of the House of Usher' and the poem 'A Dream within a Dream', have been revisited and reinterpreted in Sopor Aeternus's music. ${ }^{21}$ Aesthetic interest in mystery, 
suspense, and dread, a hallmark of Poe's fiction, is registered in the photography and videos that accompany the music, often situating Sopor Aeternus in ruined landscapes, clad in black and immersed in strong contrasts of light and shadow. Romantic motifs of what is 'lost' and 'forgotten' are prevalent, of ruins torn down by the passage of time, that cosmological time destroys and overturns everything, oblivious to man's life. For the album Have You Seen This Ghost, photographer Ingo Römling, in collaboration with photoartist Natalie Shau and illustrator Keith Thompson, created haunting images which paid homage to Harry Clarke's drawings for Poe. ${ }^{22}$ As requested by Sopor Aeternus, however, the photographs were not a simple reproduction of Poe's stories, but rather a complex reconstruction of Sopor Aeternus's fragile universe and its set of mirrors, of that intimate, spiritual world that defines the artist's way of living.

These torn presences animate the photographs and videos constructing a crypt for a melancholic contemplation inside which the physical placement and the schizophrenic movement of the performer take up tones of frantic desperation and, at the same time, become 'other' spaces in which the body itself becomes a ruin, through which the viewer-listener can mourn. The ruins celebrate the memento mori, a Vanitas of existence made of certain and irreversible death, celebrating a cult of solitude and melancholy. This imagery created by Sopor Aeternus becomes a metaphor for itself and its way of feeling, a nearly symbiotic relationship with death and with all it represents, a nostalgic, retro feeling made of graveyard memorabilia, places of natural and human disaster, a sense of impotence that leaves the viewer with mixed feelings of horror, curiosity and fascination. It is not by chance that Sopor Aeternus chooses to appear in public using what David Freedberg theorised as 'the power of images', through videos and photography, turning corporeality itself into an icon of death, in a dramatised meditation on pain and isolation. ${ }^{23}$ Videos, in fact, much like movies, are comparable to the space of a graveyard. As Giuliana Bruno states:

Cinema-like the cemetery - is a space that is home to residual body images. Film and the cemetery share this special, corporeal geography. They are sites without a geography, or rather without a fixed, univocal, geometric notion of geography [...] preserving the moment in time and space, film travels the geography of death and immortality. ${ }^{24}$

With Bruno's conception of the geographic space of film and of the body's image in place, it is possible to interpret Sopor Aeternus's own work as a type of death in life, a being that is suspended between animate and inanimate, hovering between evanescence and physicality, nerves flickering between inert matter and the human body.

One cannot help but find in Sopor Aeternus's physical, postural and expressive attitude a clear reference to funerary sculpture. First, the way in which the viewer is encouraged to approach Sopor Aeternus's images revives a phenomenon peculiar to the nineteenth century. Francis Sborgi notes a fad in which individuals would walk through graveyards, viewing the daguerreotypes of the dead with the same level of attention and concentration with which they would contemplate artworks in a museum. Picking up on Sborgi's argument regarding the 'musealisation' of the cemetery, it is possible to read Anna Varney's self-representation as a post mortem book or a 'stroll' through the images of her personal 'passing away'. ${ }^{25}$ The relation with funerary sculpture and the vacillation between corporeality, physical consistency and inert matter is particularly clear both in her photographic representations and in her video clips that, often subtly, recall the symbolic compositions of Edoardo De Albertis and Leonardo Bistolfi, the latter known as the 'Poet of Death' ${ }^{26}$ And here, in 
light of these considerations, Anna Varney's aesthetic project recalls one of the central tenets of the Pre-Raphaelites. The image, with its uncertain sexuality, so indecipherable but at the same time so close to the idea of feminine mystery, is found next to the symbolic meanings that have come to fill the woman's body, meant as 'founding principle of life, but at the same time inscrutable bearer of mystery; emblem of sensuality and eroticism, but also sign of the fugacity of beauty, which make her propose herself as privileged expression of a thought on death. ${ }^{27}$

This is where Horst Bredekamp's theories become critical for reflection on the aspects of performance in Sopor Aeternus's work. For Bredekamp, the substitutive image-act is the main reason to consider 'body and image as reciprocally interchangeable, ${ }^{28}$ As for the schematic image-act, 'the vivification of the image [...] in the form of tableau vivant, of automaton and object animation, is also true for the schematic image-act' and the artist's videophotographic performance is characterized by these same aspects, in a transformation that substitutes human features sometimes with ghostly traits, other times with sculptural post-mortem poses. ${ }^{29}$ The body's activity, as stated by Bredekamp, is connected to the construction of particular meanings and 'the images don't suffer, but produce perceptive experiences and behaviours', it is the photographs and their being put into movement that show, as in the case of Sopor Aeternus, that there is no difference between life and art, both coexist inside the same person and are shown to the public through a particular symbolic iconography that has multiple roots. ${ }^{30}$

The case of Sopor Aeternus in particular shows the multiplicity of aspects and hybridisations that today can come from literature, art, fashion both Neo-Gothic, Victorian and symbolism from the end of the 1800s and the beginning of the 1900s, turning them into a new style in continuity with the previous cultures, but projected into a social and cultural dimension that makes the artist a contemporary performer, a hybrid that is no longer tied to a collective dimension, to a unique style or trend as in the case of the PreRaphaelite Brotherhood or of the groups of artists under a same defined category or artistic period. Sopor Aeternus belongs, to all intents and purposes, to the new generation of 'mutant identities' in which bodies, behaviours, cultures, lifestyles and artistic styles are combined, making each artist a phenomenon of its own. ${ }^{31}$

For CocoRosie, the recovery and rewiring of the Neo-Gothic is quite stunningly framed in their video for 'Gallows', a track off their 2010 album Grey Oceans, directed by Emma Freeman. Formed in 2003 by sisters Bianca Leilani Casady (Coco) and Sierra Rose Casady (Rosie), CocoRosie operate on the border between indie-rock and contemporary folk. Due this indeterminacy, some critics have identified their work as being at the vanguard of several new subgenres, in particular, New American Weird, a twenty-first century style indebted to psychedelia. Their visual and sonic aesthetic, then, is a significant departure from that of Sopor Aeternus, and of Goth in general. Yet the video for 'Gallows' is exceptional in that it retains an aura of Neo-Victorian decadence and morbidity. For this reason, the article will consider 'Gallows' as detached from the wider oeuvre, looking at the narrative, photographic, and visual content of the video as a dramatic disassembly and reassembly of Neo-Victorian imagery. 
The video is considered by critics as the dark apex of the work of the two sisters; Grey Oceans is an album that collects clean sounds that are also melancholic, thanks, as is clear in the 'Gallows' video, to the introduction of the harp that makes the combination of music and images very evocative and even mystical. In fact, the lyrics to 'Gallows' subtly hint at its main topic: death and passing away. The particular intonation and the encounter of the two voices, viewed in relation to the image of the two sisters in the video, portrays them as two departed spirits. The singing is that of two supernatural souls, placed between flashes of light and darkness as if they were immersed in an ethereal and eternal wind of mysterious origin. The video is structured on several levels that alternate between the appearance of the two semi-identical sisters, a game of doubles that further enhances the communicative tension in the video; the story of a love triangle between the two twin sisters and a Byronic young man who is about to be put to the gallows for an unspecified crime. The Australian setting, with its desolate nature-filled landscape conjures the aesthetics of PreRaphaelite landscapes, characterized by a fragility that evokes the gentleness of watercolours on the one hand, and, on the other, the strength of oil painting. Just as in the Brotherhood's landscape paintings, the scenes filmed outdoors show all details in focus and this happens by 'condensing near and far into a single unit, in which each element is put in focus with the same precision. ${ }^{32}$

The video's setting and its natural components are treated as 'if they were seen through a microscope,' almost recalling the attention the painters of the Brotherhood had shown towards portraying each aspect of nature in the most realistic way possible. ${ }^{33}$ In fact there are several close-up shots of flowers, branches, animals, a nature that is in full bloom but at the same time permeated by an air of melancholy and nostalgia. The twins appear to be dressed in clothing that belongs to the Victorian era, a realisation which projects the viewer into the past, producing a temporal disjunction which foreshadows the terrible events to come. Veiled in nineteenth century fashion the twins strike the viewer as always already dead. The two creepy creatures dressed in black connect to the past through two formal devices: their poses and the representation of time. As a matter of fact, their poses recall ones that were typical of 19th century family portraits, or, more specifically, Henry Peach Robinson's artistic photography. ${ }^{34}$ But these frames from the CocoRosie video also suggest to other masters of Victorian photography such as Julia Margaret Cameron, whose 'dynamic portraits' Beaumont Newhall singles out for especial praise. ${ }^{35}$ The fruition time for these images in the video seems to slow down, almost as if, for a moment, one wanted to bring the eye to the 'necessary' time that blends painting and photography, located halfway between the fruition time for a painting and that for photography. The eye needs 'more time', a time that, in the video, is found during the brief freeze frames that remind of the long laying and preparation times for painters to paint, and for artists of early photography, to develop a photo.

Tableaux vivants as videographic freeze frames re-articulate the staged photography of the nineteenth century-recovered also, as the essay will shortly demonstrate by contemporary photographers-and in their imperceptible deathly stillness become carriers of vital characteristics. The body's stillness, according to Bredekamp, is what 'gives vitality to images', it is a presence that the spectator views empathically, as is the case for post-mortem photography or for the funerary sculptures of the nineteenth century where stone, marble, inanimate matter take on the features of departed family members, freezing the scene of death to keep its memory alive, almost wanting to relive it through the gestures in the sculptures, within a narration that 
focuses on a single talking image, just as for the most recent narrative photography. ${ }^{36}$ It is no coincidence that the twin figures in these frames, which lack a border between body and image, between physical body and incorporeal body, between reality and imagination, are, at the end, portrayed as ghostly images, immersed in the darkness by candlelight and caught in a final desperate gesture. Death and horror rule in this circumstance, but this is also a symbolic death, for the video is a real post-mortem photo album. The two dark figures, which look so real to us at first, are actually already dead, and waiting for the boy, sentenced to hanging, to re-join them in the afterlife. Death, so crucial a topic in the Neo-Gothic tradition, to romantics and decadent literature, reappears in CocoRosie's artistic production through a skilful, multilingual game that exploits every possible medium including photography, video and performance to abstract from past symbolic structures, work that can elicit a perverse fascination that is wholly contemporary.

From the interplay between music, performance, and video art, the essay will now shuttle towards photography and offer an excursus on works that have been inspired by the atmospherics, characters, and philosophical obsessions of the Neo-Gothic. Attention will be directed to a genre of contemporary photography known as 'Staged' or 'Tableau Vivant'. Works in this genre often explicitly foreground their relationship to the past and, more specifically, the figure of Ophelia, tragic heroine of that Shakespearian drama which, since Queen Victoria's reign, still solicits interest, passion, and provocation for artists. Starting with John Everett Millais Ophelia, images of bodily mortality and spiritual death have consistently been the object for artists' intent on modifying the iconography of death for their historical moment. ${ }^{37}$

As I have written elsewhere, 'to contemporary photography, the relation with art from the past is a medium in which the idea of "drawing from history" somehow means reinventing, renovating, creating something new along the lines of the feeling of the time' and this is what happens in the work of photographers such as Silvia Camporesi, Tom Hunter, Gregory Crewdson, and Brooke Shaden, who reinterpret Pre-Raphaelite artworks by transposing them into 'true staging's', inflected, however, by each individual photographers own personal stylistic and technical concerns. ${ }^{38}$

Silvia Camporesi creates a parallelism between painting and photography, 'a choreography and a staging of the context that recreates the famous painting bringing its realistic perception to the highest levels' all the while keeping the original painting clearly recognisable. ${ }^{39}$ Obversely, in his photographic series Thoughts of Life and Death, Tom Hunter 'presents contemporary reworking's of Victorian paintings, specifically those of the PreRaphaelite Brotherhood'. ${ }^{40}$ Hunter's piece The Way Home re-visualises Ophelia's suicide in a pond in the lonely wastelands on the suburban fringes of a city. Although these artists work tends towards disparate thematic and technical rules, they share a common admiration for the compositional and aesthetic harmonies of traditional painting. What their work proposes then, is not just a modern rewriting of Shakespearian drama, but of meditations on death and photographic techniques that prove themselves contemporary.

As Charlotte Cotton writes, in Tom Hunter's photography, 'with the use of large-format cameras there is a harking back to photography's history and nineteenth century fashions in tableau melodramas that became parlour-game amusements as well as cheap and collectible alternatives to prints of 
paintings' ${ }^{41}$ Cotton continues: 'In an age when digital photography has usurped analogue traditions within amateur, professional and some artistic practice, to employ larger cameras is in itself a pointed reference to forms of historical photography'. ${ }^{42}$ Hunter's work produces a three-sided remake and reinterpretation of the Neo-Gothic or Neo-Victorian context, and achieves this, not so much through a reconstruction of stylistic, architectonic, or fashion trends, but through technical accomplishments-the use of large format-that reflects early photography and, on the other hand, by creating a sensorial short circuit inside the representation where an issue from the popular press, a generic death, is represented and reconstructed by the author with clear references to older artworks. In his depiction of death and the reconstruction of the iconography of Millais's Ophelia, Hunter re-appropriates art history, innovating not just the content but also on the level of form. The evocation of Millais's painting, clearly visible through the placing of the female body and the choice of framing, is used by Hunter to critically confront the subject with the decadence of consumer society. The artist has chosen a symbolic image, one that lives in the memory of the audience, to tell a tale of contemporary despair.

Silvia Camporesi, following in the steps of Cindy Sherman, focuses instead on the conceptual mediations of feminine identity and the representation of stereotypical women's bodies in her work Studies for Ophelia from 2004. ${ }^{43}$ Shattering any sense of stable image, Camporesi explores Ophelia from a multiplicity of perspectives; however, for now, the analysis will rest on the iteration that resembles the original painting most closely. Camporesi's Ophelia, portrayed by a model and not by herself as is usual in her works, maintains a clear stylistic resemblance with the original painting where death takes on two different meanings at the same time. If, with some differences that I have examined in another context, death is personified by the model's body is proposed by Camporesi with impeccable technical expertise, the artist's work does not end with an exercise in style; instead, the picture is actually the representation of the death of the painting itself. The killing of the original painting through its re-proposition in new contemporary digital photography, together with web technologies, is carried and shown in an immediate way, made visible in real time by the whole world and at the same time extremely perishable, not conservable, an image of the evanescence of which death itself becomes victim of its commodification. ${ }^{44}$

Gregory Crewdson's work drifts further away from the original painting, often re-inscribing the human figures in dramatically different historical settings. Following the modus operandi of Jeff Wall, a contemporary Canadian photographer and artist who has been working on tableau vivant photography since the late Seventies, Crewdson, a polyedric artist, combines photography, cinematography, and art history in his work. In Crewdson's rendition of Ophelia, there are still those elements of reference that allow us to build a mental bridge between his scene and Millais's original painting, mainly by virtue of the posed body lying in water, eyes open and lifeless. Crewdson recovers the famous painting's iconography as well, to create a cinematographic, hallucinated vision of Ophelia's death in his work entitled Twilight: 'The artificial fixity of the image modifies the iconography of death, which is no longer close to the original, as in Camporesi case'. It is no longer a kind of death that gives back dignity to a common passing, as in Hunter's photography, but it pictures the completion of a suicidal act by a supernatural character, the end of a drama set in an unspecified time that awaits to be revealed, creating a state of anxiety and suspense in the viewer that waits for a turn of events'. ${ }^{45}$ 
Brooke Shaden, the youngest of these photographers, has, from 2008 on, been working on a form of photography that stresses the gap between image rendered and reality. ${ }^{46}$ Shaden's sets tend towards the fantastic and the fairytale, an artistic practice where digital post-production is a fundamental component for the final result. Her remake of Millais's piece contrasts quite sharply from the three previous cases, but it is also set apart from the traditional iconography of Ophelia that keeps continuity with the pose in the original painting. In fact, Shaden shows the drowning of the young woman from above where, in the foreground, we no longer find the beautiful ethereal face caught in the act of exhaling her last breath, but the hand gesture in the attempt to emerge from the water. The recognition of Ophelia and the continuity with the original painting here are given on one hand to the presence of flowers as symbols of vanity, and, on the other with the postproduction techniques that Shaden uses to give her images a sense of nostalgia for the past, a digital technique that makes it possible to mistake the photograph for an actual painting. The viewer does not perceive the water, as can happen within the works of the other authors; Shaden's Ophelia is inside a different context, far away from the precision of Millais's flowers, almost as if the Shaden had wanted to represent the moment in which the body sinks into the water, the moment of a dreamy oblivion, as ethereal and as terrible as only death can be. ${ }^{47}$

The necessary fruition time of the freeze frame, mentioned earlier in relation to CocoRosie, is clearly re-purposed in photography where, with considerable skill, the four photographers have each re-assembled Millais's painting in radically different contexts. Famously, Millais had to complete the painting in two phases, the first dedicated to the naturalistic composition of the scenery, the second, concretizing the void that had been left by portraying the model who had posed in his studio bathtub. The retrieval of large format photography in order to imitate previous paintings, presupposes a return to an aesthetics of contemplation, to an experience of photographic narration that is no longer immediate.

By way of conclusion, although it is impossible to exhaust such a broad and vast discussion of nostalgia for dead ages, the article has wanted, if only in a preliminary sense, to draw attention to the complexity and richness of tendencies within photography, video, and contemporary performance, that have sought to renew a relationship with the Gothic, Victorian, and PreRaphaelite style. The article has underlined the innovative aspects of stylistic maturation that these artists in particular have had towards certain periods of the history of Western society, centuries that, more than others, have had to do with the research of beauty, with a reflection on death and its representation, and with the intimacy of man before nature. The past, made of great works like Millais's Ophelia, made of topics and trends, of artistic wills that have been outlined through time, still today, speaks to the sensibility of those artists that see in it a door open on the present. The past is to this day, a unique source from which to draw, to meditate on who we are today, on the value of contemporary art and on what will be the art of the future. Each piece is original, all the while referring to works, styles, contexts and trends belonging to the past, characterised by a contemporary nostalgia for themes that, due to this actuality, show all their strength, their unending vitality within each person's sensitivity. As Marc Augé says in 'Le temps en ruines' referring to the memory of ruins, in this case, the neo-Gothic style, with all existing subcultures, and those that will be in the future, 'inspire to bring back a lost time that art, sometimes, manages to find.$^{48}$ But above all, each piece, whether 
it is visual, sonic, or performative, brings with it a nostalgia for the dramatic sentiment of previous eras: 'the melancholy of everyday life [...], the transience of time and the loneliness of all'. ${ }^{49}$

\section{University of Genoa}

\section{Notes}

$1 \quad$ Luca Beatrice, 'New Gothic: uno stile che ha contaminato l'arte come la musica, il cinema come la moda', in Preraffaelliti, l'utopia della bellezza, ed. by Luca Beatrice (Milan: 24 ORE Cultura, 2014), pp. 51-57 (p. 51). 'Prendere un periodo buio e poco esplorato nella storia dell'arte quale il Gotico, riportare alla luce qualcosa di molto lontano e soprattutto giocare una sorta di tempo sospeso e non precisamente identificato'. Ibid., p. 51 [Massarente Translation]. 'Lo stile è questo stesso curarsi del mondo, un far scaturire significati [...] Cenni semasiologici e caratteri generali'. Oscar Meo, Questioni di filosofia dello stile (Genoa: Nuovo Melangolo, 2008), p. 26 [Massarente Translation]. 'Avere stile [...] appartenere a uno stile'. Ibid., p. 29 [Massarente Translation]. 'Si riferisce a un comportamento [...] a un modo d'essere o di atteggiarsi in determinate circostanze della vita nell'ambito della sfera sociale, culturale [...] Seguire un modello generale codificato nell'ambito di una certa tradizione socio-culturale'. Ibid., pp. 29-30. 'Raduno wave e gotico [...] si tiene ogni anno a Lipsia, in Germania, in occasione della Pentecoste'. Giovanni di Iacovo, Noi siamo la note: Viaggio nelle culture Goth e Industrial (Rome: Galaad Edizione, 2014), pp. 144-145 [Massarente Translation]. Took place 14th May 2016, Genoa, Italy.

See Edward Lucie-Smith, Symbolist Art (London: Thames and Hudson, 1972), pp. 2558.

Di Iacovo, p. 12.

Important literary references would include Charles Baudelaire's The Flowers of Evil and Oscar Wilde's The Picture of Dorian Gray.

Di Iacovo, pp. 12-13.

Ibid., pp. 14-15.

Beatrice, p. 51; Di Iacovo, pp. 121-122.

Giuliana Bruno, Atlas of Emotion: Journey's in Art, Architecture, and Film (London and New York: Verso, 2007), pp. 131-169.

For a more detailed elaboration of these concepts see Horst Bredekamp, Immagini che ci guardano. Teoria dell'atto iconico, trans. by Simone Buttazzi (Milan: Raffaello Cortina, 2015), pp. 77-135 and pp. 137-186.

'L'azione è un atto performativo agito in tempo reale, a cui il pubblico non può sottostare, in cui viene costretto a provare imbarazzo, sorpresa, disgusto, eccitazione. Il corpo diviene linguaggio assoluto, medium attraverso il quale l'artista si trasforma, trasforma la propria imagine e la propria identità'. Francesca Alfano Miglietti, Identità mutanti (Milan: Bruno Mondadori, 2008), p. 25 [Massarente Translation]. Sopor Aeternus and The Ensemble of Shadows, <http://www.soporaeternus.de/ Info.html> [accessed 9 June 2016].

'Rimane vedova del Principe Alberto nel 1861 [...] a furia di utilizzare abiti neri, li transforma in una moda ancora presente ai giorni nostri'. Beatrice, p. 54 [Massarente Translation]. Enrico de Pascale, Morte e resurrezione (Milan: Electa, 2007), p. 332.

Victor Stoichita, A Short History of the Shadow (London: Reaktion Books, 1997), p. 150. Vincent Tassy, 'Interview with Sopor Aeternus: Poetica all Beauty Sleeps', Obsküre 17 (August 2013), paragraphs 5; 13. < http://www.soporaeternus.de/Interview _obsküre.html> [accessed 9 June 2016]. Ibid., par. 11.

David Freedberg, The Power of Images: Studies in the History and Theory of Response (Chicago and London: University of Chicago Press, 1989).

Bruno, p. 147. 
Franco Sborgi, Staglieno e la scultura funeraria tra ottocento e Novecento (Turin: Artema, 1997), p. 58.

26 Ibid., 180-181. For a close reading of Staglieno cemetery see pp. 175-208.

27 'Principio generatore della vita, ma allo stesso tempo imperscrutabile portatrice del mistero; emblema della sensualità e dell'Eros, ma anche malinconico segno della fugacità della bellezza-fanno si che essa si ponga come espressione privilegiata di un pensiero sulla morte'. Ibid., 181 [Massarente Translation].

. 137.

Ibid., p. 137.

Ibid., p. 265.

See Miglietti's ground breaking Identità mutant (Milan: Mondadori, 2008).

Jason Rosenfeld, 'Landscapes', in Preraffaelliti, l'utopia della bellezza, trans. by Alessandra Gallo, Claudia Valeria Letizia, and Arianna Ghilardotti. Ed. by Tim Barringer, Jason Rosenfeld, and Alison Smith (Milan: 24 ORE Cultura, 2014), pp. 120121 (p. 120).

Ibid., p. 121.

For instance Henry Peach Robinson, Fading Away in Beaumont Newhall, The History of Photography (London: Secker and Warburg, 1972), p. 60.

Newhall, p. 64.

Bredekamp, p. 78.

Jason Rosenfeld, 'John Everett Millais, Ophelia 1851-52', Preraffaelliti, l'utopia della bellezza, trans. by Alessandra Gallo, Claudia Valeria Letizia, and Arianna Ghilardotti. Ed. by Tim Barringer, Jason Rosenfeld, and Alison Smith (Milan: 24 ORE Cultura, 2014), pp. 74-76.

'Per la fotografia contemporanea il rapporto con l'arte del passato costituisce un medium con cui l'idea di "attingere dalla storia" significa in qualche modo re-inventare, rinnovare, creare qualcosa di nuovo in linea con il sentire del proprio tempo'. Martina Massarente, 'L'artista e la sua opera come fonte di ispirazione. Reinterpretazione, citazione e reinvenzione dell'Ofelia di John Everett Millais nella fotografia contemporanea', Senzacornice 18 (April/July 2016), pp. 1-11 (p. 2) [Massarente Translation]. Lucilla Meloni, Arte guarda arte. Pratiche della citazione nell'arte contemporanea (Milan: Postmedia books, 2013). 'Costruendo un interessante parallelismo tra pittura e fotografia, una coreografia e una messa in scena del contesto che ripropone il famoso dipinto portandone al Massimo livello la percezione realistica.' Massarente, p. 5 [Massarente Translation].

Charlotte Cotton, The Photograph as Contemporary Art (London: Thames and Hudson, 2004), p. 54.

Ibid., p. 55.

Ibid., p. 55.

Silvia Camporesi, 'Studies for Ophelia', < http://silviacamporesi.it/ofelia/> [accessed 9 June 2016].

For more on Silvia Camporesi see Marinella Paderni, Laboratorio Italia. La fotografia nell'arte contemporanea (Monza: Johan and Levi Editore, 2009) and Massarente 2016. 'La fissità artificosa dell'immagine modifica l'iconografia della morte che non si mostra più vicina all'originale, come nel caso di Camporesi. Non è più una morte colta per restituire dignità a un decesso comune, come nella fotografia di Hunter, ma raffigura il compimento di un tempo non precisato che attende solo di essere svelato inducendo nello spettatore ansia e suspance in attesa di un colpo di scena'. Massarente, pp. 8-9 [Massarente Translation]. For a bio see < http://brookeshaden.com/about/> [accessed 9 June 2016]. The photo comes from a series called The Re-Imagining of Ophelia. Shaden has previously spoken about her indebtedness to characters or figures from literary and cultural history: 'Definitely. More than anything else there are recurring spaces in which different characters exist. For example, I have many images set in the forest with the same dark brooding backdrop, but different characters who explore that world. Each of those characters are different, hence making the images different, but they all explore similar themes. I also have certain characters that come back time and time again, like the classic fairy tale character of Little Red Riding Hood who I absolutely adore, and a series that I did on Ophelia from Hamlet [...] I love the works of Gregory Crewdson perhaps more than any other due to his amazing planning skills and how cinematic everything is. There are some people who can spin a yarn and his are the most captivating to me. As far as inspirations for my own work, probably the biggest comes from sources outside of photography. I love the Pre-Raphaelite painters as well as movies like Pan's Labyrinth and my favourite book is Dune by Frank Herbert. 
< http://www.life-framer.com/2013/12/18/interview-brooke-shaden/> [accessed 10 June 2016].

48 Marc Augé, Rovine e macerie, trans. by Aldo Serafini (Turin: Bollati Boringhieri, 2004).

49 'In una malinconia del quotidiano [...] la transitorietà del tempo e la solitudine di tutti'. Franco Sborgi, 'La solitudine di tutti', in Sussurri, ed. by Martina Massarente and Daniel Nevoso (Genoa: Sagep, 2012), pp. 59-60 (p. 59) [Massarente Translation].

\section{Works Cited}

Alfano Miglietti, Francesca, Identità mutanti (Milan: Bruno Mondadori, 2008)

Augé, Marc, Rovine e macerie, trans. by Aldo Serafini (Turin: Bollati Boringhieri, 2004)

Barringer, Tim and Jason Rosenfeld, 'L'avanguardia vittoriana', trans. by Alessandra Gallo, Claudia Valeria Letiza, and Arianna Gihlardotti in Preraffaelliti, l'utopia della bellezza, ed. by Tim Barringer, Jason Rosenfeld, and Alison Smith (Milan: 24 ORE Cultura, 2014)

Beatrice, Luca, 'Gothland: L'enigma preraffaellita tra musica, moda, cinema e arte', in Preraffaelliti, l'utopia della bellezza, ed. by Tim Barringer, Jason Rosenfeld, and Alison Smith (Milan: 24 ORE Cultura, 2014), pp. 51-57

Bredekamp, Horst, Immagini che ci guardano. Teoria dell'atto iconico, trans. by Simone Buttazzi (Milan: Raffaello Cortina Editore, 2015)

Bruno, Giuliana, Atlas of Emotion: Journey's in Art, Architecture, and Film (London and New York: Verso, 2007)

Camporesi, Silvia, 'Studies for Ophelia', < http://www.silviacamporesi.it lofelia/> [accessed 10 June 2016]

CocoRosie, <http://www.cocorosiemusic.com/> [accessed 9/06/2016] , 'Gallows', < https://www.youtube.com/watch?v=oiEqWYawpeU $>$ [accessed 9 June 2016]

Cotton, Charlotte, The Photograph as Contemporary Art (London: Thames and Hudson, 2004)

Crewdson, Gregory, 'On set Ophelia', < http://www.gregorycrewdson

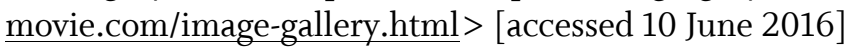

De Pascale, Enrico, Morte e Resurrezione (Milan: Electa, 2007)

Di Iacovo, Giovanni, Noi siamo la notte. Viaggio nelle culture Goth e Industrial (Rome: Galaad Edizioni, 2014)

Freedberg, David, The Power of Images: Studies in the History and Theory of Response (Chicago and London: University of Chicago Press, 1989)

Hunter, Tom, < http://www.tomhunter.org/life-and-death-in-hackney/> [accessed 10 June 2016]

Lucie-Smith, Edward, Symbolist Art (London: Thames and Hudson, 1972)

Massarente, Martina, 'L'artista e la sua opera come fonte di ispirazione. Reinterpretazione, citazione e reinvenzione dell'Ofelia di John Everett Millais nella fotografia contemporanea', Senzacornice 18, (April/July 2016), pp. 1-11

Meloni, Lucilla, Arte guarda arte. Pratiche della citazione nell'arte contemporanea (Milan: Postmediabooks, 2013)

Meo, Oscar, Questioni di filosofia dello stile (Genoa: Nuovo melangolo, 2008)

Newhall, Beaumont, The History of Photography (London: Secker and Warburg, 1972)

Paderni, Marinella, Laboratorio Italia. La fotografia nell'arte contemporanea (Monza: Johan \& Levi Editore, 2009) 
Rosenfeld, Jason, 'John Everett Millais, Ofelia, 1851 - 52', trans. by Alessandra Gallo, Claudia Valeria Letiza, and Arianna Gihlardotti in Preraffaelliti, l'utopia della bellezza, ed. by Tim Barringer, Jason Rosenfeld, and Alison Smith (Milan: 24 ORE Cultura, 2014), pp. 74-76

, 'Landscapes', trans. by Alessandra Gallo, Claudia Valeria Letiza, and Arianna Gihlardotti in Preraffaelliti, l'utopia della bellezza, ed. by Tim Barringer, Jason Rosenfeld, and Alison Smith (Milan: 24 ORE Cultura, 2014), pp. 120-121

Sborgi, Franco, 'La solitudine di tutti', in Sussurri, ed. by Martina Massarente and Daniel Nevoso (Genoa: Sagep editori, 2012), pp. 59-60 , Staglieno e la scultura funeraria ligure tra Ottocento e Novecento (Turin: Artema, 1997)

Shaden, Brooke, Inspiration in Photography (Burlington: Focal Press, 2013) , 'Life-Framer Interview' < http://www.life-framer.com /2013/12/18/interview-brooke-shaden/> [accessed 10 June 2016] , < http://brookeshaden.com/gallery/> [accessed 9 June 2016]

Sopor Aeternus and the Ensemble of Shadows, $<$ http://www.soporaeternus.de /Info.html> [accessed 9 June 2016]

Stoichita, Victor, A Short History of the Shadow (London: Reaktion Books, 1997)

Tassy, Vincent, 'Interview to Sopor Aeternus: Poetica all beauty sleeps', Obsküre 17 (August 2013), < http://www.soporaeternus.de /Interview_OBSKÜRE.html $>$ [accessed 9 June 2016] 